ACTA UNIVERSITATIS LODZIENSIS

FOLIA LITTERARIA POLONICA 1(47) 2018

http://dx.doi.org/10.18778/1505-9057.47.05

Beata Przymuszała*

\title{
Strategia przetrwania. Brygada śmierci Leona Weliczkera
}

Zwrócenie uwagi na to, jak ktoś sam może modelować własne reakcje emocjonalne, tak, by próbować powstrzymać napór obozowej rzeczywistości, jednocześnie nie tracąc z nią kontaktu (co prowadziło niemal zawsze do poddania się jej, pochłonięcia), nie należało do często podejmowanych problemów w piśmiennictwie obozowym. I z tego powodu warto przyjrzeć się książce Brygada śmierci - wspomnieniom Leona Weliczkera z jego pobytu w obozie i w Sonderkommando.

\section{Weliczker}

Autor miał 14 lat, gdy wybuchła wojna; przedstawiony przez niego życiorys brzmi jak nieprawdopodobna historia. Po wkroczeniu Niemców do Lwowa był kilka razy w więzieniu, z którego za każdym razem udawało mu się uciec. Dwukrotnie jednak wracał do niego z własnej woli, zgłaszając się zamiast wzywanego ojca. Podczas pobytu w więzieniu został skazany na rozstrzelanie - będąc już na miejscu egzekucji (wykopał razem z innymi więźniami grób) - uciekł, wrócił do domu, potem dostał się do „lasu”. Gdy dowiedział się o śmierci matki i czterech sióstr, przedostał się do lwowskiego getta, do ojca i braci, stamtąd - już sam - trafił do obozu janowskiego, w którym przez pięć miesięcy i pięć dni był w brygadzie śmierci - skąd uciekł 20 listopada 1943 roku i ukrywał się do lipca 1944. We Lwowie jednak nie pozostał, przeniósł się do Gliwic (Polskę opuścił po pogromach w $1946 \mathrm{roku})^{2}$.

* Dr hab., adiunkt; Uniwersytet im. Adama Mickiewicza, Instytut Filologii Polskiej, Zakład Semiotyki Literatury; ul. Fredry 10,61-701 Poznań; beaprzy@amu.edu.pl.

${ }^{1}$ L. Weliczker, Mój życiorys, w: tenże, Brygada śmierci (Sonderkommando 1005). Pamiętnik, Ośrodek „Brama Grodzka - Teatr NN”, Lublin 2012 (reprint wydania z 1946 r.), s. 25-27.

${ }^{2}$ Tę informację przytaczam za Arkadiuszem Morawcem, autorem wstępu do reprintu książki Weliczkera. Morawiec doprecyzowuje także sytuację „ucieczki znad grobu”: ucieczkę „umożliwił" mu jeden z Niemców, odwołując go na chwilę do obozu - tam udało mu się ukryć i dopiero potem wydostać z obozu. Zob. A. Morawiec, Wstęp, w: L. Weliczker, Brygada śmierci..., s. XIV. 
Historia nieprawdopodobna w potocznym tego słowa znaczeniu, bo wydaje się niemożliwe, by ktoś miał tyle szczęścia (?), determinacji (?), siły (?) - by wbrew temu, co się działo, podejmować ryzyko, więcej - samemu się na nie „wystawiać" (myślę zwłaszcza o pójściu do więzienia zamiast ojca). Auerbach pisała, iż „,zdolność radzenia sobie w trudnym i niebezpiecznym położeniu występuje u niego [tj. Weliczkera - przyp. B.P.] w wysokim stopniu". Podkreśla przy tym: „Nie rezygnuje z życia, nie poddaje się fatalizmowi grawitacji do zagłady, której tylu Żydów somnambulicznie ulegało. Próbuje się ratować i szczęście mu sprzyja"’. Te niemal na gorąco pisane słowa brzmią dziś niejednoznacznie: trudno bowiem z perspektywy lat, które przynosiły coraz więcej informacji o realnych możliwościach ratowania się przed Zagładą - czyli o niemal braku takowych - myśleć o „uleganiu”, ale nie można zapomnieć, że autorka pisze o jego lunatycznym nacechowaniu (tak jakby poddani niszczeniu Żydzi przestali być sobą, jakby dali się wprowadzić w stan burzący jakiekolwiek rozeznanie). Ocena Auerbach wskazuje - po części intuicyjnie, ponieważ nie o wszystkim wtedy było wiadomo - na problem nieistnienia świadomości tego, co się działo, na brak możliwości realnego rozeznania własnej sytuacji, co prowadziło do poddawania się bieżącym wydarzeniom. Koniecznie należy przy tym podkreślić, iż Żydzi, wierzący, że jadą do pracy, wierzący, że oprawca „nie kłamie”, niekoniecznie robili to w pełni świadomie, najczęściej działały tu mechanizmy obronne, odsuwające z pola percepcji informacje zbyt obciążające psychikę.

$\mathrm{W}$ tym znaczeniu zestawienie Weliczkera $\mathrm{z}$,somnambulicznie ulegającymi zagładzie Żydami” jest nieadekwatne, ponieważ autorowi Brygady śmierci uniemożliwiono nawet snucie złudzeń - nie tylko już w więzieniach otarł się dosłownie o śmierć, ale, jakby tego było mało, został skierowany w miejsce, gdzie był naocznym świadkiem skali dokonywanego przez Niemców mordu i w jego tuszowaniu musiał uczestniczyć.

Młody wiek i siła fizyczna Weliczkera były tymi cechami, które działały na jego korzyść. Ale jednocześnie przecież młody wiek wiązał się z dużą bezbronnością wobec wszystkiego, co widział i czego doświadczał. Redagująca zapiski Auerbach pisała, iż, przygotowując je do druku, usunęła urywki świadczące o pewnej naiwności autora (przede wszystkim dotyczące uczuć do zamordowanej rodziny i wyrażające współczucie dla ofiar), pozostawiając jedynie niektóre fragmenty „w pierwotnej, niezaradnej ich postaci, aby świadczyły o wzniosłej postawie moralnej młodego Żyda, stanowiącej najcenniejsze dziedzictwo i własność jego uratowaną z zagłady"

Zwracam uwagę na tę „naiwność”, istotną zwłaszcza w zestawieniu ze świadomością tego, co musiał oglądać i co musiał robić Weliczker. Powyż-

\footnotetext{
${ }^{3}$ R. Auerbach, Uwagi wstępne, w: L. Weliczker, Brygada śmierci..., s. 13.

${ }^{4}$ Tamże, s. 16.
} 
sza uwaga redaktorki mogłaby zostać potraktowana jako dowód na zaliczenie Brygady śmierci do ujęć „martyrologicznych” - cudzysłów, który stosuję, zaznacza duży dystans co do możliwości potraktowania wspomnień z Sonderkommando jako podniosłych. A jednak słowa o przejściu przez to miejsce $\mathrm{z}$ „budującą postawą moralną” wydają się temu nie przeczyć. By spróbować przybliżyć możliwe sposoby ujmowania wskazanego paradoksu, proponuję przyjrzeć się właśnie kwestii emocjonalnego podejścia autora książki do opisywanych doświadczeń.

\section{Obóz - „nie myśleć”}

Wąwóz ten jest jednym wielkim grobem masowym, mieszczącym tysiące trupów. $\mathrm{Z}$ boku na górze leżą stosy drzewa. [...] Maszyna pompuje oliwę [...]. Ogień syczy. Czy może syczą ci, którzy się palą? A może palą ich żywcem? Za kilka chwil będę pewnie wiedział wszystko.

„Habt keine Angst” - zaczyna Untersturmführer swoje przemówienie. „Będziecie tu pracowali, a gdy skończy się ta praca pójdziecie z powrotem do obozu".

Słuchamy z niedowierzaniem. Już my ich dobrze znamy. Czy wszyscy wywiezieni na śmierć nie pojechali również na ,robotę"? [...]

Mnie, jako tego, który się wybija wzrostem, biorą pierwszego, a po mnie jeszcze dwóch. [...] idziemy do miejsca pracy, zostawiając resztę za sobą. Nie myśleć, czy tak jest dobrze, czy źle! Co może być złego, skoro dzieje się już to najgorsze? Może dlatego wybrał tylko trzech, żeby tam pozostała okrągła liczba 40, a nas zaprowadzi do ognia? Po co myśleć? O ucieczce teraz mowy nie mas .

Powyższy fragment przedstawia pierwsze zetknięcie z miejscem „pracy” brygady śmierci, oddaje reporterski styl Weliczkera, mocno jednak przełamywany osobistymi wtrętami przypominającymi strzępy wewnętrznego monologu. Autor konsekwentnie prezentuje stopniowy wzrost wiedzy, konfrontując ją z krążącymi w obozie opowieściami, i wreszcie swój „galop myśli”, który ma zostać powstrzymany przez uspokajające słowa: „nie myśleć” - niebędące tutaj retoryczną wstawką. To, co pojawia się przed oczami czytelnika, jest odtwarzaną sceną przeżycia czegoś, co wymyka się wszystkiemu, co znane, co możliwe do wyobrażenia. Spokój przywołany przez autora zapisków ma sens dwojaki: chodzi o próbę wyciszenia natłoku wrażeń, emocjonalnego pobudzenia, które szybki przepływ myśli może jeszcze wzmacniać, powodując coraz większą dezorientację (co byłoby śmiertelnym zagrożeniem), a jednocześnie ten spokój - postrzegany

\footnotetext{
${ }^{5}$ L. Weliczker, Brygada śmierci..., s. 36-37.
} 
jako zewnętrzne opanowanie - będzie sprawiał wrażenie silnego zdystansowania się, pewnej aemocjonalności.

Analizując z dzisiejszej perspektywy opis Weliczkera, mamy świadomość, iż autor przedstawia swoje reakcje na zdarzenie wywołujące silną traumę: nie tylko widzi stosy zamordowanych ludzi, ale także zdaje sobie sprawę z tego, że w każdej chwili on sam może stracić życie. Obraz, który otrzymaliśmy, jest zapisem ,przeżywanej traumy”: w tym kontekście przytoczone słowa skierowane do samego siebie - „nie myśleć” - wskazują na pierwszy, niemal odruchowy sposób „radzenia sobie” z rzeczywistością. Korzystając z pojęć współczesnej psychologii, można je określić jako próbę wpływania na własne reakcje emocjonalne, by nie doprowadziły one do zwiększenia poczucia przerażenia (a tym samym wzrostu odczuwanego cierpienia).

\section{Modulowanie emocji}

Kwestia modulowania emocji należy do podstawowych zagadnień współczesnej psychologii; wskazując na związki między reakcjami emocjonalnymi a wymogami otoczenia, pozwala rozwijać badania nad kulturowymi i społecznymi uwarunkowaniami wyrażania uczuć 6 . Podkreślanie wspólnotowego aspektu kontrolowania emocji nie oznacza jednak, że psychologowie pomijają indywidualne uwarunkowania tego typu reakcji, zwracają jednak uwagę, iż nie są one na tyle odmienne, by uniemożliwić ich rozpoznanie przez inne osobyํ. Najczęściej jednak różnice w reagowaniu wynikają z negatywnych doświadczeńn ${ }^{8}$, do podstawowych zaś przyczyn uruchamiających zniekształcony przebieg emocji należą przeżycia traumatyczne. Kontrola emocji może doprowadzić do ich wyciszania, tłumienia w taki sposób, by można było obronić się przed zbyt trudnym doświadczeniem lub by osłabić oddziaływanie wydarzenia niemożliwego do przyjęcia dla psychiki. Badania nad traumą pokazują, iż do jednej z reakcji na traumatyczne zdarzenia należy dysocjacja polegająca na „odmiennym od normalnego stanie świadomości, który jest konsekwen-

\footnotetext{
${ }^{6}$ Zob. W. Łosiak, Psychologia emocji, Wydawnictwa Akademickie i Profesjonalne, Warszawa 2007, s. 141-164.

${ }^{7}$ J.R. Averill, Nieodpowiednie i odpowiednie emocje, w: Natura emocji. Podstawowe zagadnienia, pod red. P. Ekmana, R.J. Davidsona, przeł. B. Wojciszke, Gdańskie Wydawnictwo Psychologiczne, Gdańsk 2002, s. 230.

${ }^{8}$ Jak zaznacza Averill: „W konsekwencji (lub dla skompensowania) dysfunkcji fizjologicznych, niewłaściwej socjalizacji, zaburzeń motywacyjnych czy deformacji poznawczych, jednostka może znacznie odchylić się od reguł konstytutywnych [dla wyrażania danej emocji - przyp. B.P.] obowiązujących w danym społeczeństwie. Takie osobiste (w odróżnieniu od społecznie podzielanych) reguły emocji pozwalają jednostce na wyrażanie jej potrzeb i pragnień, jednak w wysoce specyficzny i często «zaburzony» sposób”. Tamże.
} 
cją ograniczenia lub zmiany w dostępie do myśli, uczuć, percepcji i wspomnień" I właśnie z odsuwaniem się, odcinaniem się od własnych myśli mamy do czynienia w przytoczonym fragmencie zapisków autora Brygady śmierci.

Należy podkreślić, iż przywołana definicja dotyczy sytuacji po ustaniu traumatycznego wydarzenia, przytaczam ją jednak z dwóch powodów: po pierwsze, nie można wykluczyć, iż w przypadku szczególnie zagrażającej sytuacji proces tłumienia emocji pojawia się od razu (gdyż przeżycie jest na tyle silne, że mechanizm obrony zaczyna natychmiast funkcjonować), po drugie, zapiski Weliczkera powstawały częściowo po pobycie w Sonderkommando - mogą więc zostać potraktowane jako tworzone zarówno w czasie, jak i po ustaniu zagrożenia. Chociaż można wyznaczyć w odniesieniu do traumatycznego przeżycia wyraźną linię oddzielającą czas bezpośredniego poddania zdarzeniu od czasu późniejszego, to jednak nie sposób nie przyjąć, iż przez cały okres mamy do czynienia z trwaniem traumy (która jedynie ma różne fazy).

Weliczkera „nie myśleć”, mające odsunąć świadomość możliwej śmierci, przywołuje obraz osoby „opanowującej się”, pragnącej nie poddać się przerażeniu. Rachela Auerbach, opisując sylwetki więźniów, którzy zdołali przeżyć obozy, zauważa: „występuje u ludzi tych zdolność jak najbardziej celowego akomodowania swoich afektów, zdolność unikania tego wszystkiego, co mogłoby spowodować tzw. załamanie psychiczne"10. Umiejętność unikania obciążających sytuacji pojawia się we wspomnieniach Weliczkera wprost, gdy autor opowiada historię mężczyzny (,niejaki Brill”), który zaraz po przywiezieniu do obozu został rozdzielony z córkami i trafił do komanda: tego samego dnia zobaczył ich zwłoki (pracował przy paleniu trupów). Weliczker, przywołując tę historię, zwraca uwagę na sposób, w jaki została mu ona przedstawiona: „Opowiada pomału, jakby wciąż kogoś widział przed sobą. Uświadamia sobie, czy to on - ten sam. Do każdego słowa dodaje długie, głębokie «oj». Często też urywa w pół słowa, połyka coś, a później zamiast kończyć to słowo dodaje jeszcze jedno «oj»" Zwróćmy uwagę na beznamiętne przytoczenie przez autora Brygady śmierci opisu zetknięcia się ojca z ciałami zamordowanych córek, które za chwilę będzie musiał ujrzeć w ogniu - Weliczker dokładnie opisuje wypowiedź osoby będącej w szoku. Trudność mówienia wskazuje zarówno na stan dezorientacji, jak i oddaje narastające cierpienie związane z powracaniem widoku młodych kobiet. Celny jest komentarz wysłuchującego tej historii: Brill może mieć wrażenie, jak domyśla się Weliczker, poczucia rozpadania się siebie (to, czego doświadczył, poraziło go całkowicie, niszcząc mechanizmy obronne). Uważnie obserwując współwięźnia, autor wspomnień stwierdza w pewnym momencie: „Jeszcze coś dalej mówił,

${ }^{9}$ J. Briere, C. Scott, Podstawy terapii traumy. Diagnoza i metody terapeutyczne, przeł. P. Nowak, Instytut Psychologii Zdrowia. Polskie Towarzystwo Psychologiczne, Warszawa 2010, s. 40.

${ }^{10}$ R. Auerbach, Uwagi wstępne, s. 14.

${ }^{11}$ L. Weliczker, Brygada śmierci..., s. 49. 
jęczał, stękał, rzucał rękoma i nogami, jak obłąkany, ale już go nie słuchałem. W czemże mogłem mu pomóc?"'12.

Wrażenie bezduszności, które odczuje czytelnik, wypływa zarówno z przykładania pozaobozowych norm do sytuacji wymykającej się rozumieniu, jak i z małej świadomości procesów, które zachodzą $\mathrm{w}$ trakcie kontaktu z czyimś cierpieniem ${ }^{13}$. Warto przy tym pamiętać, iż Weliczker jest czujnym obserwatorem; lapidarne wtrącenia pokazują, iż domyśla się, co dzieje się z jego rozmówcą: nie sposób posądzić go o brak odczuwania. Można natomiast powiedzieć, że jest odwrotnie - wyobrażając sobie, co czuje ojciec zamordowanych córek (poczucie rozpadu samego siebie), zachowuje w stosunku do niego dystans. Nie dlatego, by nie chciał mu pomóc - raczej wiedząc, że nie jest w stanie nic dla niego zrobić, odcina się od usłyszanej historii, by samemu jej nie przeżywać, by siebie nią nie obciążać.

Istotnym kontekstem dla powyższych rozważań jest dalszy opis wieczoru i nocy po rozmowie z Brillem. Zostawiwszy rozpaczającego mężczyznę, by się odizolować, Weliczker po pewnym czasie wraca i próbuje rozmawiać o ucieczce. Myśl o niej pojawia się co jakiś czas w zapiskach, świadcząc o potrzebie wzmacniania własnego oporu, tworzenia dystansu wobec otaczającej go rzeczywistości (jakby budował sobie w ten sposób rodzaj strefy ochronnej). Słysząc odpowiedź Brilla, że dla niego nic już się nie liczy, że chce umrzeć, komentuje to następująco: „teraz człowiek ten jest nieżywy, duszy nie ma"14. Słowa te, odnosząc się do jego stanu po śmierci córek, jednocześnie podkreślają będące jego efektem odrętwienie, takie zapadnięcie się w siebie, które zagraża życiu. Zarazem są to słowa wskazujące na to, co ważne dla Weliczkera: by przetrwać, musi on próbować zachować w sobie to, co pomoże mu siebie ocalić.

Przytoczona rozmowa, ukazująca autora, który, zmieniając temat, usiłuje przestać pogrążać się we współcierpieniu i zacząć planować to, co może pomogłoby im razem się uratować, sugeruje, iż cały czas próbuje on powstrzymać napór otaczającej go rzeczywistości. Nie dopuszczając - jak podkreśla redaktorka książki - do załamania, wciąż szuka sposobów osłabiania lub blokowania emocji. O tym, jak są one silne i jak mocno obecne w jego psychice, świadczą sny, jakie miał w nocy po rozmowie z Brillem.

\footnotetext{
12 Tamże, s. 50.

${ }^{13}$ Badacze zajmujący się traumą zwracają uwagę na zjawisko tzw. traumy zastępczej, pojawiającej się przede wszystkim u osób niosących poszkodowanym szeroko rozumianą pomoc. Wprawdzie mowa tu o personelu służb ratunkowych i psychoterapeutach, ale sam mechanizm powstawania traumy wskutek współprzeżywania cudzych doświadczeń może zostać zastosowany do przybliżania sytuacji osób znajdujących się w warunkach, w których ilości otrzymywanych traumatycznych wiadomości i bycie świadkiem takich zdarzeń przekracza doświadczenie nawet tych osób, które należą do służb ratunkowych (a takim było doświadczenie obozowe). Zob. J. Briere, C. Scott, Podstawy terapii traumy..., 24. Psychologowie przestrzegają przed tym współprzeżywaniem.
}

${ }^{14}$ L. Weliczker, Brygada śmierci..., s. 50. 
Weliczker pisze, że śniła mu się świąteczna kolacja, na której był razem $\mathrm{z}$ całą swoją rodziną (z której pozostał już tylko on sam) - wybudza go dochodzący z niedaleka płacz dzieci („czekają na wyzwolenie, którym ma być śmierć”15 - dopowiada). Gdy znów zasypia, widzi swojego najmłodszego brata płaczącego ze strachu przed czekającym go końcem - Weliczker uspokaja brata, mówiąc, że śmierć trwa tylko moment, a potem będzie już z rodzicami. Po sennym obrazie pojawia się kolejny - jak zaznacza autor - pochodzący z rzeczywistości:

Jedną matkę zastrzelono, a dziecko siedzi koło niej w kałuży krwi, trzymając głowę na jej piersiach i śpi. Później podchodzi SS-owiec i bije je nahajką, by poszło wraz z innymi dziećmi na ,piaski”, a ono krzyczy: „Mamo, boli!”. Dziecko wstaje, zaczyna uciekać, a on idzie za nim. Dziecko krzyczy. Nareszcie morderca decyduje się zastrzelić dziecko na miejscu. Wyjmuje rewolwer - pada strzał i od tego strzału budzę się. Widocznie musiał faktycznie wystrzelić ktoś koło baraku, a płacz dzieci i coś jakby stłumiony szloch dorosłych ludzi dochodzi z placu za drutami, gdzie tamci siedzą i czekają ${ }^{16}$.

Sen przerwany hałasem śnionym i faktycznym należy do analizowanych przez psychologów przykładów przetwarzania przeżytych w ciągu dnia wydarzeń i sytuacji. W przypadku Weliczkera sen, zakończony wystrzałem nierealnym i jednocześnie realnym, przypomina o niemożności ucieczki przed rzeczywistością. I nie chodzi tu o rodzaj efektownej konkluzji: przedstawione przez autora wspomnień sny pokazują siłę przeżywanych przez niego emocji, które - chociaż wyciszone w ciągu dnia - wracają nocą wraz ze wszystkimi wywołującymi je zdarzeniami i odczuciami.

Sny, które zostały opisane, dotyczą relacji między dziećmi i rodzicami oraz rodzeństwem i wszystkie mogą być odebrane w kontekście przeprowadzonej tego dnia rozmowy z Brillem. Pokazywałyby (na zasadzie pewnej analogii) jak mocno opowiedziana przez niego historia podziałała na Weliczkera (a tym samym - przed czym się bronił).

Wśród reakcji potraumatycznych wymienia się właśnie obrazy senne, w których powracają sprawiające cierpienie sytuacje ${ }^{17}$, trudno jednak nie dostrzec, iż w omawianych zapiskach - powstających w czasie bezpośredniego doświadczania porażających wydarzeń - koszmarne obrazy pojawiają się od razu, co więcej, są prawie wiernym powtórzeniem zdarzeń doświadczanych na jawie. Jakby podkreślały wszystko, przed czym przeżywający traumę chce uciec, odsłaniały to, co w ciągu dnia było wypierane ze świadomości.

\footnotetext{
15 Tamże, s. 50.

16 Tamże.

${ }^{17}$ J. Briere, C. Scott, Podstawy terapii traumy..., s. 36.
} 
Przytoczone powyżej fragmenty zapisków pokazują w dużym zbliżeniu sposoby, przy pomocy których, funkcjonując w Sonderkommando, Weliczker stara się odeprzeć wszystkie informacje i zdarzenia mogące doprowadzić go do załamania. Budowanie ochronnej zapory z pewnością pojawiało się przynajmniej wśród niektórych członków komanda; ci, którzy nie próbowali się chronić, ginęli, nierzadko popełniając samobójstwo. Weliczker opisuje taki właśnie przypadek, który wydarzył się na początku jego pobytu w brygadzie. Na problem ten wskazują też opowieści innych „sonderowców”. Rozmówca Krystyny Żywulskiej w Auschwitz mówi: ,jeśli nie wariuje się pierwszego dnia... potem można się przyzwyczaić”18. Gideon Greif, opisujący podobną sytuację, podkreślał:

Początkowy szok był dla większości nowych więźniów Sonderkommando przeżyciem tak traumatycznym, że popadali w stan całkowitej apatii. To zobojętnienie należy definiować jako mechanizm obronny, który być może był dla tych ludzi, stojących przed stosami zwłok, jedynym sposobem na pozostanie przy zdrowych zmysłach i na przeżycie ${ }^{19}$.

Weliczker w przywołanych powyżej sytuacjach (i tej dotyczącej nakazanego sobie „niemyślenia”, i dystansowania się wobec historii ojca zamordowanych córek) sam wskazywał na konieczność ,wyłączenia się" z rzeczywistości, wprost podkreślając, iż zdawał sobie sprawę z ochronnego aspektu takich zachowań. Nawet jeśli była to wiedza na pograniczu świadomości, co jest normą w przypadku mechanizmów obronnych, faktem jest, że autor zapisków stosował wobec siebie samego celowo zabiegi niedopuszczające do jeszcze większych cierpień.

Również oprawcy stosowali podobne działania, które miały doprowadzić do „otępienia” więźniów, ale w ich przypadku istotne było wywołanie stanu zobojętnienia u osadzonych, który spowoduje, iż będą oni pracować, nie buntując się. Inne były też prowadzące do tego stanu metody.

\section{Manipulowanie emocjami}

Weliczker często wskazywał na zmuszanie przez esesmanów więźniów do udawania, że to, co się dzieje, nie dzieje się naprawdę, a także nieujawniania przez nich tego, jak wydarzenia, w których uczestniczą, oddziałują na ich psychi-

\footnotetext{
${ }^{18}$ K. Żywulska, Przeżyłam Oświęcim, Dom Wydawniczy tCHu, Państwowe Muzeum Auschwitz-Birkenau, Warszawa-Oświęcim 2008, s. 221.

${ }^{19}$ G. Greif, ,,...płakaliśmy bez łez...”. Relacje bytych więźniów żydowskiego Sonderkommando z Auschwitz, przeł. J. Kapłon, Żydowski Instytut Historyczny, Państwowe Muzeum Auschwitz-Birkenau, Warszawa-Oświęcim 2007, s. 83.
} 
kę. To, że konieczność zatajenia procesu zagłady objęła swym zasięgiem także zmuszonych do uczestniczenia w niej więźniów, nie dziwi, ale zaskakuje podjęta przez Niemców próba wywierania wpływu na świadomość i emocje członków komanda.

O tym, że powinni udawać przed esesmanami zadowolonych, więźniowie dowiadują się najpierw od szupowców ${ }^{20}$ : „Szupowcy doradzają nam, byśmy byli na pozór zawsze weseli, byśmy udawali, że jesteśmy zadowoleni z naszej roboty, bo złą minę przypłacić możemy życiem" ${ }^{21}$. Mamy tutaj jeszcze do czynienia z sugestią, która jest oparta na przekonaniu o konieczności udawania emocji (ale im nie przeczy). Inaczej podchodzą do tego Niemcy odpowiadający za akt mordowania:

Trupy zanosili do ognia. [...] Z drugiej strony stał Zähler, trzymając w ręku ołówek i papier. Zadanie jego polega na tym, że notuje on ilość trupów, które się wrzuca na ogień. Nawet szupowcom nie wolno mu mówić, ile trupów spalono w ciągu dnia. Wieczorem zdaje Untersturmführerowi dokładny raport o ilości spalonych trupów. Jemu samemu nie wolno pamiętać, ile trupów spalono poprzedniego dnia. Gdy Untersturmführer pyta się na drugi dzień, ile trupów spalono wczoraj, to musi powiedzieć, że zapomniał. Trupy nazywa się „figurami”. Wrzucając trupy wchodzi się aż pod sam ogień. Każdy z pracujących przy tej robocie ma ręce, twarz i włosy osmalone $^{22}$.

Naturalny (w przypadkach zakładających tajność) zakaz przekazywania informacji zostaje poszerzony o nonsensowny - jak się może wydawać w pierwszej chwili - zakaz pamiętania. I chociaż nikt nikomu nie może nakazać „niepamiętania", to jednak wywieranie presji na świadomość jest chwytem manipulacyjnym wywołującym poczucie dezorientacji: zmuszeni do wykonywania absurdalnych poleceń mają wątpić w zdolność rozeznania otoczenia (istotny nie jest faktyczny efekt - niemożliwy do sprawdzenia, ważny pozostaje jednak nieustanny nacisk na więźniów). Podważanie zaufania do własnych reakcji miało jeszcze szerszy i bardziej ,subtelny” zasięg:

Tak samo, jak po tamtej egzekucji i dziś przyszedł Untersturmführer zobaczyć, jakie mamy miny. Może nie jesteśmy zadowoleni, to będzie trzeba przeprowadzić dziś jeszcze jedną egzekucję. [...] On dalej szedł powolnym krokiem, patrząc każdemu w oczy, jakby chciał wyczytać, co się u każdego w sercu dzieje. Każdy ma w tej chwili uśmiechniętą twarz. [...] Teraz Untersturmführer posuwa się pomału kilka kroków

\footnotetext{
${ }^{20}$ Szupowcy, jak podaje Weliczker, to nie zawodowi policjanci, ale niemieccy rezerwiści - zmuszeni do służby, nieuczestniczący osobiście w mordowaniu Żydów. Zob. L. Weliczker, Brygada śmierci..., s. 64.

${ }^{21}$ Tamże, s. 65.

${ }^{22}$ Tamże, s. 42-43.
} 
dalej i zatrzymuje się przy stojącym obok mnie robotniku, który nie ma - jak mu się zdaje - dosyć uśmiechniętej twarzy. Mówi, że poznaje po jego minie, że tamten jest niezadowolony. Chce koniecznie usłyszeć prawdę. Mój sąsiad się usprawiedliwia, thumaczy, że patrząc komuś w oczy musi mieć poważną minę - ale Untersturmführer żali się kiwając głową, że wszyscy go okłamujemy ${ }^{23}$.

Opisana scena może być zinterpretowana jako próba narzucenia więźniom pożądanego zachowania: mają nie tylko nie wyglądać na przerażonych czy obojętnych, ale sprawiać wrażenie aprobujących. Warto zwrócić uwagę na proces wymuszania nie jedynie pozornej zmiany, lecz na podjętą przez oprawców próbę wpłynięcia na psychikę więźniów. Nakazując utrzymywanie określonej mimiki, oprawcy wywołują konieczność wyrażania innych emocji niż odczuwane, co często powoduje dodatkowe cierpienie. Weliczker wspomina o tym przy okazji opisu wymarszu do pracy, podczas którego więźniowie musieli śpiewać: „Serce płacze, a usta śpiewają"24.

Niemożność wyrażania emocji prowadzi często do ich wyciszania. Mogą one jednak być zastępowane pożądanymi przeżyciami w taki sposób, żeby zmniejszyć wrażenie dyskomfortu między własnym odczuciem a tym, co ma być ujawnione.

\section{Kontrolowanie emocji a trauma}

Świadoma decyzja o niedopuszczaniu do siebie określonych obrazów czy myśli mogła być wspierana automatycznym odruchem wycofania się z dostępu do całej rzeczywistości i odwrotnie: uruchomione obronne reakcje mogły być wzmocnione kontrolowaniem przeżyć emocjonalnych. Fakt, że Weliczker sygnalizuje własne odczucia, nie wyklucza przecież tego, iż niektóre z nich pozostają poza zakresem jego samowiedzy. Wspominane już przeze mnie zjawisko dysocjacji (ograniczenia dostępu do własnych myśli, uczuć, wspomnień) część psychologów traktuje jako taki rodzaj doświadczeń, które mają prowadzić do „psychicznego unikania cierpienia emocjonalnego" 25 . Przy czym sama dysocjacja (mająca typowo obronny wymiar, uruchamiająca się często nieświadomie) może pojawiać się także przy innych - nie uznawanych za traumatyczne - zdarzeniach ${ }^{26}$, ma więc bardziej ogólny charakter. Jednocześnie stosowana przez autora Brygady śmierci emocjonalna samokontrola służyła mu właśnie do ochrony przed wzrostem cierpienia. Oba więc sposoby działania - zarówno rzadko prze-

\footnotetext{
23 Tamże, s. 77.

24 Tamże, s. 65.

${ }^{25}$ J. Briere, C. Scott, Podstawy terapii traumy..., s. 41.

${ }^{26}$ Tamże.
} 
biegający świadomie proces emocjonalnego wyłączania się, jak i podjęty świadomie sposób modulowania, osłabiania własnych uczuć - służą ochronie osoby przed nadmiernym psychicznym obciążeniem. Co więcej, jak podkreśla się w badaniach nad traumą, jej przebieg zależy zawsze od indywidualnych czynników i jednym z nich (oprócz takich uwarunkowań, jak wiek, płeć, status społeczny, wcześniejsze przeżycia, typ osobowości itp.) jest właśnie sposób emocjonalnego przeżywania samej traumy:

Chociaż uważa się je czasem za właściwość samej traumy [...], to cierpienie emocjonalne jest prawdopodobnie w równej mierze indywidualną cechą ofiary, co miarą nasilenia stresora. Wydaje się, że osoby, które w czasie traumy doświadczają szczególnie silnego cierpienia, powinny być bardziej narażone na problemy pourazowe, $\mathrm{z}$ licznych powodów, takich jak uprzednio istniejące (to znaczy, przed traumą) problemy z tolerancją na stres i z regulacją afektu, wcześniejsza ekspozycja na traumę oraz kognitywna predyspozycja do postrzegania wydarzeń życiowych jako czegoś, co jest poza kontrolą i stanowi potencjalne zagrożenie ${ }^{27}$.

Warto zwrócić uwagę na pojawiający się w przytoczonym fragmencie rozważań autorów Podstaw terapii traumy tryb przypuszczający: analizując indywidualny wymiar traumatycznego przeżycia, nie sposób wyprowadzać uogólniających stwierdzeń. Każdy przypadek, co oczywiste, rozważa się osobno, a zauważone podobieństwo niektórych reakcji nie powinno przesądzać o budowaniu modelu.

Istotne jednak pozostaje zwrócenie uwagi na samą możliwość istnienia związku między własnymi sposobami emocjonalnego reagowania a przeżywaniem traumy: nie chodzi przy tym o wskazanie jednostronnej zależności (nie sposób powiedzieć, iż osoba, która dobrze sobie radzi z „regulacją afektu”, osłabi oddziaływanie traumy). Odnosząc powyższe uwagi do zapisków Weliczkera, można jedynie stwierdzić, iż oprócz prawdopodobnego pojawiania się mechanizmów automatycznie osłabiających oddziaływanie otaczającej go obozowej rzeczywistości, on sam świadomie próbował zachowywać się w sposób wspomagający osłonę własnej osoby przed jeszcze mocniejszym natężeniem cierpienia.

Przeprowadzone przeze mnie analizy sposobów zachowywania się członków Sonderkommando wskazują, że poza działającymi mechanizmami obronnymi uruchamiali oni także (mniej lub bardziej świadomie) różne procesy, pozwalające im nie zwiększać własnego cierpienia, po to, by mogli przeżyć. Z jednej strony należeli do więźniów, którzy z uwagi na fizyczne warunki (zarówno jeśli chodzi

${ }^{27}$ Tamże, s. 29. 
o stan zdrowia, jak i jedzenie, i spanie) mieli więcej siły, by pobudzić siebie do dbania o swój stan psychiczny. Ale z drugiej strony wszystko, czego doświadczali, było do tego stopnia traumatyczne, że ich funkcjonowanie prowadziło najczęściej do niszczenia samych siebie: i nie chodzi w tym przypadku tylko o popełniane samobójstwa. Jedno ze zdań Weliczkera mówiące, że zamordowani mają lepiej niż oni, nie było jedynie „racjonalizacją” dowcipów na temat zwłok, odsłaniało prawdę o ludziach zmuszonych do zniszczenia samych siebie własnymi rękami. Mechanizmy obronne, zarówno nieświadome, jak i świadome, chociaż zapewniały przetrwanie (przynajmniej przez jakiś czas), prowadziły jednak do podważenia poczucia własnej tożsamości. Fakt, iż jednocześnie Niemcy prowokowali sytuacje, w których więźniowie zmuszeni byli odcinać się od własnych odczuć, mógł zwiększać ich poczucie winy, będąc dodatkowym elementem opresji: jeśli esesmani zmuszali członków komanda do zachowań, które oni sami u siebie stosowali, mogło to prowadzić do samooskarżenia pojawiającego się na granicy świadomości (o celowe ,znieczulanie się” wobec tego, co się działo, wobec bycia świadkiem zagłady). Manipulacja dokonana przez oprawców opierałaby się na porażająco prostym i zarazem przerażającym pomyśle: to, co bywa stosowane jako mechanizm obronny, staje się nakazem, niszczącym zarówno poczucie własnej autonomii (co było generalnym założeniem faszystowskiego totalitaryzmu), jak i opierające się na dostępie do własnych emocji poczucie kontaktu z rzeczywistością i samym sobą.

Zmuszeni do bycia obok dokonującej się zagłady więźniowie Sonderkommando także wtedy, gdy próbowali siebie chronić, realizowali (w części przynajmniej) wytyczne oprawców: obojętniejąc, by żyć, funkcjonowali na granicy rzeczywistości - nie odczuwali jej. Ci, którzy przetrwali, wracając po latach do tamtego okresu i mówiąc o sobie, że żyli jak zwierzęta, nie tylko odsłaniają proces własnej depersonalizacji, ale i wskazują na postrzeganie siebie poza społeczną rzeczywistością. Sprowokowani do "nieludzkiego” (w potocznym tego słowa znaczeniu) zachowania, dostosowawszy do niego własne ,ja”, znaleźli się nie tylko poza „ludzkim”, ale i obozowym światem, co było ogromnym sukcesem Niemców.

Trzeba jednak wspomnieć, że i oni musieli liczyć się z dokonaną w ten sposób wyrwą w lagrowym porządku. Jak wspominał jeden z więźniów, Abraham Dragon, „esesmani bali się więźniów Sonderkommando, byliśmy «poza prawem»"28. Tłumaczył sobie ich reakcję tym, że więźniowie, nie mając nic do stracenia (bo w każdej chwili mogli zginąć), bywali postrzegani jako realne zagrożenie dla Niemców. Ale czy działała w tym przypadku jedynie obawa o własne życie, czy pojawił się również lęk przed ludźmi naznaczonymi wykonywaniem takiej pra-

${ }^{28}$ A. i S. Dragonowie, ,,W zwatpieniu i nadziei-zawsze byliśmy razem!”, w: G. Greif, ,...płakaliśmy bez łez...”, s. 131. 
cy, trudno powiedzieć. Tym bardziej, iż tego rodzaju lęk mógł działać na progu świadomości.

Jak wspominałam, przytaczając fragment książki Krystyny Żywulskiej, więźniowie unikali członków Sonderkommando. Autorka Przeżyłam Oświęcim pisała, że, widząc ich, widzi ,potwory”, nie wyobrażała sobie, by ludzie mogli tak pracować ${ }^{29}$. Także Weliczker opisuje, jak reagowano na nich, gdy pojawiali się w obozie, odsłania przy tym ,inny punkt widzenia” - to, jak sonderkommandowcy odbierali zachowanie pozostałych więźniów:

Ludzie z obozu widząc, że nasza brygada idzie w ich kierunku, schowali się do baraków, a my maszerując, śpiewaliśmy. Przykro nam było, że ludzie nas się boją. Tak strasznie przecież nie wyglądaliśmy? To nasi dwaj Brandmeistrzy, którzy w swoich czapkach z rogami na głowie i z hakami w ręku wyglądali, jak prawdziwe diabły - wzbudzali taki popłoch ${ }^{30}$.

Tłumaczenie opisanej reakcji obecnością „,diabłów” odsłaniałoby pewną nieświadomość Weliczkera, ale nie wyjaśniałabym tego przypadku sygnalizowaną przez redaktorkę jego zapisków młodzieńczą naiwnością ${ }^{31}$. Wydaje się, że dużo bardziej istotne jest mimowolne odsłonięcie własnego niedopuszczania do świadomości tego, do czego zmuszeni zostali więźniowie - co byłoby sygnałem zarówno wspomnianej kontroli emocji, jak i stosowania mechanizmów obronnych, które, ograniczając przeżycia, nie pozwalają jednocześnie uzmysłowić sobie, jak doświadczana sytuacja może być odbierana przez innych ${ }^{32}$.

\section{Bibliografia}

Auerbach Rachela, Uwagi wstępne, w: Weliczker Leon, Brygada śmierci (Sonderkommando 1005). Pamiętnik, Ośrodek „Brama Grodzka - Teatr NN”, Lublin 2012, s. 11-23.

Averill James R., Nieodpowiednie i odpowiednie emocje, w: Natura emocji. Podstawowe zagadnienia, pod red. Paula Ekmana i Richarda J. Davidsona, przeł. Bogdan Wojciszke, Gdańskie Wydawnictwo Psychologiczne, Gdańsk 2002, s. 316-322.

Briere John, Scott Catherin, Podstawy terapii traumy. Diagnoza i metody terapeutyczne, przeł. Paweł Nowak, Instytut Psychologii Zdrowia. Polskie Towarzystwo Psychologiczne, Warszawa 2010.

\footnotetext{
${ }^{29}$ K. Żywulska, Przeżyłam Oświęcim, s. 220.

${ }^{30}$ L. Weliczker, Brygada śmierci..., s. 89.

${ }^{31}$ Zob. R. Auerbach, Uwagi wstępne, s. 16.

${ }^{32}$ Warto tu przywołać słowa Leona Cohena: „W momencie, w którym wypieraliśmy się tych uczuć, czuliśmy się jak «normalni ludzie», traktowaliśmy to wszystko, jak «pracę», którą musimy wykonywać według wskazówek Niemców”. L. Cohen, „, Nie byliśmy juz ludźmi, byliśmy robotami”, w: G. Greif, ,...płakaliśmy bez łez...”, s. 324. Nie sposób tu nie wspomnieć też przywołanej rozmowy Żywulskiej z więźniem z komanda specjalnego, który starał się jej wytłumaczyć ich sytuację - miałby więc on świadomość tego, jak mogą być oceniani z zewnątrz.
} 
Greif Gideon, „....płakaliśmy bez łez...”. Relacje bytych więźniów żydowskiego Sonderkommando z Auschwitz, przeł. Jan Kapłon, Żydowski Instytut Historyczny, Państwowe Muzeum Auschwitz-Birkenau, Warszawa-Oświęcim 2007.

Łosiak Władysław, Psychologia emocji, Wydawnictwa Akademickie i Profesjonalne, Warszawa 2007.

Morawiec Arkadiusz, Wstęp, w: Weliczker Leon, Brygada śmierci (Sonderkommando 1005). Pamiętnik, Ośrodek „Brama Grodzka - Teatr NN”, Lublin 2012, s. VII-XXIV.

Weliczker Leon, Brygada śmierci (Sonderkommando 1005). Pamiętnik, Ośrodek „Brama Grodzka - Teatr NN", Lublin 2012.

Żywulska Krystyna, Przeżyłam Oświęcim, Dom Wydawniczy tCHu, Państwowe Muzeum Auschwitz-Birkenau, Warszawa 2008.

\section{Beata Przymuszała}

\section{A way of survival. Leon Weliczker's The Brigade of Death}

\section{Summary}

This article discusses the testimony of Leon Weliczker (The Brigade of Death), who was at the Sonderkommando in the Janowska camp. Describing the daily focus on the removal of corpses Weliczker simultaneously reveals his ways of survival. Discourse on trauma focuses on its subsequent impact, in the case of the analyzed text we are dealing with an attempt to record the traumatic state. Using the psychological context, the author shows how Weliczker tried to minimize the impact of trauma using various mechanisms of controlling and displacing emotions.

Keywords: Extermination; Janowska camp; Sonderkommando; trauma; control of emotions 